\title{
China's Global Diplomacy: Introduction to the Special Issue
}

\author{
Paul Sharp | ORCID 0000-0002-8906-0186 \\ Department of Political Science, University of Minnesota, Duluth, \\ Minnesota, United States \\ psharp@d.umn.edu \\ Jan Melissen | ORCID 0000-0002-1312-0808 \\ Institute of Security and Global Affairs, Leiden University, The Hague, \\ The Netherlands; Department of Political Science, University of Antwerp, \\ Antwerp, Belgium \\ j.melissen@fgga.leidenuniv.nl
}

Qingmin Zhang

Peking University, Peking, People's Republic of China zhangqingmin@pku.edu.cn

The rise of China is no longer just a possibility to be imagined. It is an established fact. So too are the increasing impact that a more powerful and confident China is having on the rest of the world, and the increasing impact that the rest of the world is having on China. Both are unprecedented. China's interaction with the rest of the world provides a window on how a rising China practices diplomacy. This provides new challenges to which students of contemporary diplomacy in China and in the rest of the world must respond with study and research. We are pleased to present this special issue of The Hague Journal of Diplomacy on China's Global Diplomacy as part of such an effort.

This collection of research articles and forum pieces was long in the making. The editors owe a great debt of thanks to all of the contributors for the extraordinary patience they have shown as the collection slowly came together. All in all, it was well over two years from first conception to publication. When we began, President Donald Trump's attempts to redress the US-China trade 
balance and change Chinese economic practices were just gathering steam, China's wolf warrior diplomacy had not yet been named as such, and, of course, COVID-19 and the global pandemic associated with it were unknown. From that point, our contributors, like everyone else, laboured under conditions of increasing uncertainty. When we began, we were aware that China and the world were facing changes on a scale, as President Xi Jinping expressed it, 'not seen in 100 years'. However, it was possible to assume that these changes could be understood in terms of a familiar story in international relations about the emergence or, in China's case, re-emergence of a great power/major country on the world stage. How would China's and everyone else's diplomacy manage this development? To what extent would China be socialised into the prevailing order based on Western norms, and to what extent would China's 'new option', the 'Chinese approach' and, indeed, the 'China model' begin to make their own contribution to how international life would be ordered in future?

As readers will see from the following collection, these themes of socialisation and adjustment have not disappeared. Even in the worst of times, the ordinary diplomacy of issuing visas, maintaining an active social media presence, and accommodating a legion of new participants in international life persists. All receive treatment in this collection. It is also important to remember that Chinese diplomacy should not be seen entirely through the prism of East-West tension and great-power struggle. A large, although perhaps now shrinking, amount of Chinese diplomacy is conducted without any reference at all to those dramas. Nevertheless, in the two years during which this collection was created, remarkable changes have taken place. China's view of the world has shifted.

Instead of seeing the world as a source of economic growth and technical development, it is now viewed as a platform on which China's political independence and strategic autonomy are to be achieved and safeguarded. The rise of Chinese power and US efforts to decouple from China in key technical sectors have combined to produce high diplomacy of the worst sort between the two superpowers - assertions and counter assertions of hostile intent, disrespect and bad faith designed to demonstrate resolve, but also to inflame. And the consequences of these exchanges have percolated downwards into the low diplomacy of travel, trade and study, made more difficult by the pandemic, by political uncertainties, and by the sharply worsening images that Chinese people and Westerners have of each other's countries. People-to-people relations are weakening. In the context of these changes, writing about Chinese diplomacy is like venturing out onto ice that is getting thinner, and our contributors are to be congratulated for persisting with their efforts. 
The research articles begin, appropriately enough, with a piece of diplomatic history - Wang Li and Yaotian Fan's study of how Zhou Enlai guided China's diplomacy in the 1950s and 196os through an emergence that was possibly even more difficult than the present one. The challenge for a new power is to find a place for itself in the world and to secure international acceptance of that place, while, at the same time, remaining true to its own core principles and interests. Zhou succeeded in this, Li and Fan argue, by employing a characteristically Western diplomatic principle — creating confidence — with a characteristically Chinese diplomatic principle — creating order that holds within it the ability to change - a truly diplomatic solution to a diplomatic problem.

The second essay, by Pauline Kerr, calls into question how well Zhou's approach to diplomacy is currently being applied. It does so by examining China's evolving encounter with the diplomatic norms of the Association of Southeast Asian Nations (ASEAN), the 'ASEAN Way', with special reference to disputes in the South China Sea. Kerr argues that through the first decade of this century, Chinese diplomacy evolved from accepting the conduct suggested by ASEAN Way norms to seeking exemptions from that conduct, and finally to challenging it and advancing its own norms. By employing a diplomatic studies approach, however, Kerr argues that this shift is not explained simply by China's rising power allowing it to be more demanding. Rather, China's tactics are a matter of choices that reflect its own preferences and the subsequent consequences of employing those tactics. In the medium-to-long-term, China is reshaping the norms of the environment in which its South East Asian diplomacy is conducted, and that changed environment is, in turn, shaping China's preferences within it. However, as Kerr suggests, it is achieving this without creating the confidence and goodwill that were so important to China's diplomatic success under Zhou.

The next two research articles remind us that even as international temperatures rise, routine forms of diplomacy - both established and innovative persist and develop. Liping Xia examines how China has responded to the expanding demand for consular protection services from Chinese citizens since the 18th Party Congress in 2012 and its call for China's diplomacy to be transformed. Some of the themes the article identifies will be familiar to students and practitioners of consular diplomacy elsewhere; for example, the demand to do more with resources spread ever more thinly, the attempt to ease this pressure by employing private and semiprivate agencies to provide 
some services and the increasing importance of educating citizens working and travelling abroad about their rights and duties and what consular services can and cannot do for them. Others may be less familiar; for example, the sheer pace at which demand for Chinese consular services is ramping up, the tendency to see the level of respect that is given to Chinese citizens abroad as measure of host countries' willingness to respect the international standing of China as a whole and the importance that the Chinese government attaches to co-ordinating the activities of consular agents - both new and old - with core Chinese foreign policy objectives as these are articulated by the central government.

The themes of transforming diplomacy and co-ordinating new actors are also present in Chen Wei's article on the growing role of cities in China's diplomacy. Two related questions are posed by the article. First, do the international relations of Chinese cities conform to 'club' models of diplomacy hierarchically organised around elites - or do they conform to 'network' models of diplomacy in which shifting coalitions of actors manoeuvre and temporarily cluster around nodes of resources and channels of communication, building relations across China's borders? Second, can the diplomatic efforts of Chinese cities be located in the context of the central government's policy of transforming Chinese diplomacy and contributing to the transformation of global governance? The article argues that the Chinese version of city diplomacy exhibits features of both club and network diplomacy, and, in doing so, may be seen as part of a centrally directed and co-ordinated national effort.

In the final research article, Ingrid d'Hooghe shifts the focus of the collection away from the substance of China's diplomacy at various levels and towards the way that China presents itself to the rest of the world. Chinese public diplomacy is shifting, the article argues, from a previous emphasis on China's culture and its contribution to civilisation - China's soft power of attraction in the eyes of the rest of the world. Instead, the Chinese government is presenting a new story based on China's more recent successes, the model of governance by which it says these have been achieved and the gifts that both have put it in a position to offer a world seeking harmonious development towards a community of common destiny. The article notes, however, that the story has become more focused and more political, while those engaged in delivering it have become smaller in number and narrower in type.

China's storytelling is taken up by four of the five forum contributions; one explicitly, two in the context of other themes. Kerry Brown notes the role of the Chinese Communist Party as the great storyteller at home offering a progressive, optimistic narrative shaped by Marxism Leninism but grounded 
in a cultural narrative of lost and recovered national status. Telling the story abroad, however, is more difficult, so difficult that the party has barely tried until recently. Foreign audiences regard communism with various degrees of scepticism and do not have an emotional stake in the cultural and national sides to the story. This has changed with Xi and China's presentation of the Belt and Road Initiative. The difficulties remain, however, and to Western ears, at least, the external version of the China's story often sounds bland, platitudinous and disconnected from what China's foreign policy is actually doing and its diplomacy is often saying.

This disconnect is explored by Qingguo Jia. China, he notes, has tried hard to establish a role for itself as a responsible major power country and stakeholder in the international order. For example, it has become involved in international peacekeeping operations, collaborated with other states to combat climate change and contributed to the fight against CoviD-19 global pandemic. However, its efforts to act responsibly have faced much opposition from Western states. Jia suggests this is for several reasons. The speed of China's rise has surprised everyone, including many Chinese themselves, and the West is troubled by its perceptions of the way China has developed. However, the West's own domestic problems in general, and policies of the Trump administration in particular, have added to its uneasiness at China's rise.

Has Chinese diplomacy done all it can to smooth the country's path? In her discussion of Chinese international discursive power, Jisheng Sun notes that developing the ability to have an international position and voice that is listened to with desired consequences is very difficult. It took decades, for example, before the discursive power of the United States accurately reflected the material base of American wealth and power. Nor is it simply a matter of committing resources to the effort. The exercise of discursive power remains a skill that is developed dialectically by paying attention to what your audiences want to hear as much as what you want to tell them. To judge from China's success in developing its positions and influence in international organisations, it is a skill in which Chinese diplomacy is becoming stronger, but the sources of this success are not easy to identify. Is it the particularly Chinese characteristics of Chinese diplomacy?

Qingmin Zhang is doubtful about this. Chinese diplomacy, he suggests, is distinctive but perhaps not in the way in which most Chinese scholars have suggested. Some of their suggestions - for example, China's focus on independence and peace - are not particular to China. Others, such as anti-hegemonism and establishing new principles for major power country relations, are neither particular to China nor, properly speaking, diplomacy. 
They are foreign policies. Among the things particular to Chinese diplomacy, Zhang argues, are its attempts to represent China as a major country and a developing country at the same time, and, of course, the role of the Communist Party in guiding the state organs of diplomacy and in conducting its own diplomacy.

After surveying the history of China's international engagement, Chas W. Freeman also takes up the theme of distinctive features in Chinese diplomacy. Foremost of these is the contrast between, on the one hand, China's inflexibility on what it regards as core interests - for example, sovereignty and independence - and, on the other, its ability to create and tolerate high levels of flexibility and ambiguity at a tactical level as evidenced by the Shanghai Joint Communique regarding Taiwan. Another contrast is between the way China has tended to use military power as a clearly defined and limited component of a political strategy - the interventions in India and Vietnam, for example, and the ambiguity with which it exercises economic leverage. Sanctions such as the denial of access to China's markets are sometimes imposed without a clear reason being specified, leaving the target nation unclear regarding what it must do to get them lifted. However, one way in which China's diplomacy is becoming less distinctive, Freeman notes, is in the tendency of some its diplomats to follow the trend by other major powers of giving high-profile media performances primarily addressed to audiences back home. Whether it is done with Chinese characteristics or anyone else's characteristics, he suggests, this can generally be regarded as ineffective diplomacy.

\section{3}

Conclusion

As can be seen from this collection of articles and forum contributions, Chinese diplomacy in a time of great change exhibits ordinary, general and exceptional features. At the level of ordinary, everyday international life, China's diplomats face similar constraints, developments and the challenges of adjusting to them, to those confronted by the diplomats of other countries. The rising demand for consular services and rising expectations of what those services should include, for example, is not a Chinese problem but a diplomatic one. Even at the international level, China's rise presents a familiar diplomatic problem the Thucydides trap to which Xi has referred. How do you get others to give you more space than they have been previously willing to grant without giving unnecessary offence? Perhaps a measure of offence and the willingness to give it are necessary components of a diplomacy directed at changing a country's status in the international pecking order. But then, how can a country know if it is underplaying or, more dangerously, overplaying its hand in this regard? 
Nineteenth-century America, by a combination of good luck, good geography and good political principles got this right. Twentieth-century Germany did not. How 21st-century China's new global diplomacy deals with this challenge depends, in large part, on conditions that are exceptional to China. As this collection of articles and essays makes clear, the scale of the challenge that its diplomats face remains, for the moment, much clearer than the response that they ought to take to it.

This special issue also has theoretical intentions. Careful readers may find differences between Chinese and non-Chinese contributors, not only in their views but in their styles of narrating China's diplomacy. This indicates a gap between them and has implications for both. The non-Chinese contributors are long-time China watchers, and some have rich and personal experience with China's diplomacy. Their insightful observations represent how the world looks at and understands that diplomacy. However, there is shortage of scholars of general diplomatic studies, especially those who theorise diplomacy. Due to language and cultural obstacles, scholars in the field of diplomacy theory have not brought China under their research radar. This is a pity, because China offers a gold mine for empirical studies. Any international theory of diplomacy that ignores the Chinese experience, or that cannot be applied to the Chinese experience, cannot really be regarded as a fully international theory. It is imperative for these scholars to turn their eyes to China and bring Chinese diplomacy into their study to enrich their empirical bases and enhance the relevance of their theory.

It is equally important for scholars of diplomacy in China to bridge international diplomatic theories and Chinese diplomatic studies. Diplomatic studies in China sometimes seem either too general or too sensitive in their approaches to the subject, at least to Western eyes. On the one hand, it is difficult to find a domain in China that has been more open to international influences than the practice and the study of diplomacy. Different forms of diplomacy spring up quickly, and now there may be more scholars engaged in the study of diplomacy in China than in any other country. On the other hand, the popular Chinese saying that 'diplomacy is no small matter; the power belongs to the central government', has made diplomacy a sensitive and mysterious subject and has constrained its study. As a consequence, those who study diplomacy in China sometimes confuse their subject with the object of their study, those who actually make and implement foreign policy. Echoing the government's view, Chinese scholars emphasise what is special about China's diplomacy, while neglecting the fact that it is one case of international diplomacy. Chinese scholars of diplomacy need to go beyond actor-general international relations theories of power politics and to bring in international diplomatic theory and bridge the gap between their study of China's diplomacy and theories 
of diplomacy from elsewhere. China should not simply be a producer and exporter of industrial products; it also needs to contribute Chinese experience and Chinese wisdom, including in the field of international diplomacy.

\section{Paul Sharp}

is a Professor of Political Science at the University of Minnesota Duluth in the United States. He is the author of three books and two textbooks. In addition, he has co-edited four books and authored numerous articles, all on aspects of diplomacy, foreign policy and international relations in general.

\section{Jan Melissen}

is the Editor-in-Chief of The Hague Journal of Diplomacy, Senior Fellow at Leiden University's Institute of Security and Global Affairs, The Hague Campus, The Netherlands, and Professor of Diplomacy in the Department of Political Sciences at the University of Antwerp, Belgium. He is also a Non-Resident Fellow with the Center on Public Diplomacy at the University of Southern California, Los Angeles. He has a wide-ranging research interest in diplomacy in theory and practice and has done commissioned research on change and innovation in diplomacy for governments in Europe and the Asia-Pacific. Over the years he has published over ten books, and he is the Editor of the Brill Diplomatic Studies Series. He has recently published peer-reviewed research articles in International Affairs, Global Policy, Asia \& the Pacific Policy Studies, International Studies Review, Global Affairs, and European Foreign Affairs Review.

\section{Qingmin Zhang}

is a Professor and the Chair of the Department of Diplomacy, the School of International Studies, Peking University. His teaching and research interests include diplomatic studies and theory of foreign policy analysis with an empirical focus on China. He is the author of Contemporary China's Diplomacy (China International Press 2014, 2020) and Foreign Policy Analysis (Peking University Press 2019). He has translated from English to Chinese Woodrow Wilson and Colonel House: A Personality Studies (Central Compilation \& Translation Press 2014), Groupthink: Psychological Studies of Policy Decisions and Fiascos (Central Compilation \& Translation Press 2016) and Diplomacy in a Globalizing World: Theories and Practice (Shanghai People's Press 2020). He has also contributed many book chapters and articles to scholarly journals, including The Hague Journal of Diplomacy, Journal of Contemporary China, The Chinese Journal of International Politics and Journal of Chinese Political Science as well as several leading Chinese journals in international studies. 